\title{
Carpal tunnel syndrome caused by remitting seronegative symmetrical synovitis with pitting oedema
}

\author{
Britta Nijsse, Gerwin Roks
}

Department of Neurology, St Elisabeth Hospital, Tilburg, The Netherlands

\section{Correspondence to} Britta Nijsse, b.nijsse@ elisabeth.nl
To cite: Nijsse B, Roks G. BMJ Case Reports Published online: 28 November 2012 doi:10.1136/bcr-2012007347

\section{DESCRIPTION}

A 73-year-old man presented with paresthesias of the fingertips and weakness of the abductor pollicis brevis muscle and the opponens pollicis muscle of both hands. Carpal tunnel syndrome (CTS) was suspected and confirmed by electromyography. The presence of swelling and pitting oedema of both hands (figures 1 and 2) led to the diagnosis of remitting seronegative symmetrical synovitis with pitting oedema (RS3PE).

RS3PE is a rheumatological clinical syndrome, distinctive of rheumatoid arthritis and polymyalgia rheumatica. It occurs predominantly in elderly men and is characterised by rapid-onset symmetrical synovitis, pitting oedema especially on the dorsum of the hands, negative rheumatoid factor and a dramatic response to low doses of glucocorticoids (prednisone $10-20 \mathrm{mg} /$ day). ${ }^{1}$

Few studies report the correlation of RS3PE with CTS. An incidence of $22-43 \%$ is reported. ${ }^{2}{ }^{3}$ CTS symptoms completely resolve after treating RS3PE with steroids. Every neurologist should recognise CTS, but this does not always relate the swollen hands to RS3PE. Owing to the presumed paraneoplastic aetiology, it is important to recognise the syndrome. Several reports about RS3PE-associated malignant conditions were published, mostly adenocarcinomas or haematological malignancies. ${ }^{1}$ This created the presumption of RS3PE being a paraneoplastic manifestation. The search for occult malignancy is particularly crucial in patients with systemic symptoms and those who are not responsive to steroids.

The symptoms in our patient completely resolved after steroid treatment and analysis showed no signs of malignancy.

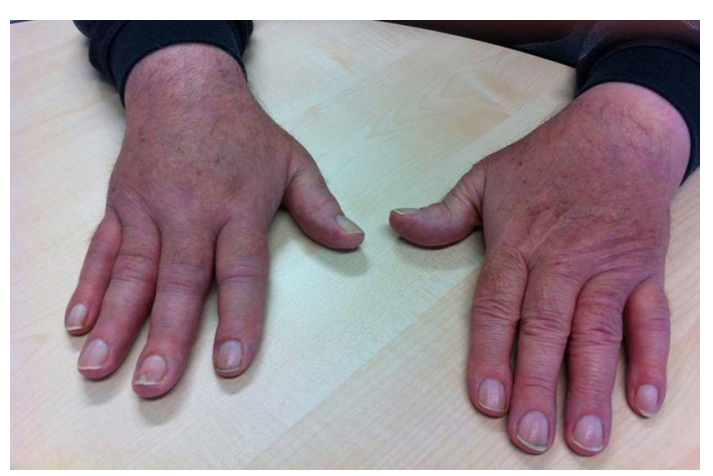

Figure 1 Prominent swelling of both hands.

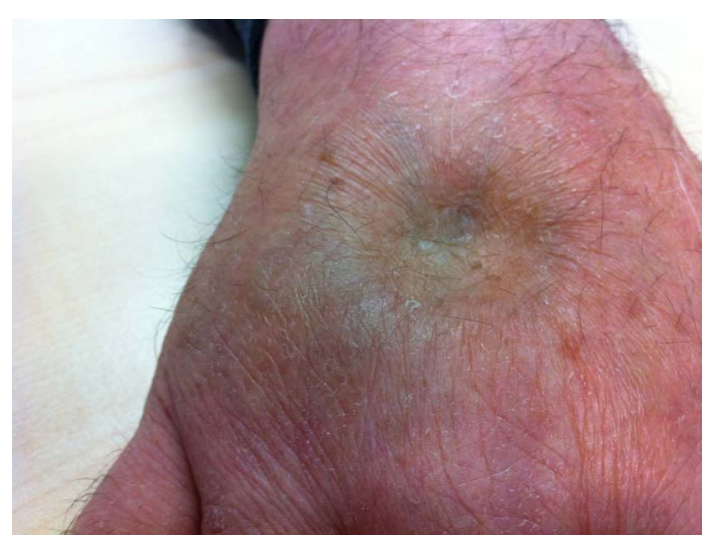

Figure 2 Pitting oedema of the hands.

\section{Learning points}

- If Carpal tunnel syndrome (CTS) goes together with swollen hands and pitting oedema, the diagnosis of remitting seronegative symmetrical synovitis with pitting oedema (RS3PE) should be considered.

- Given the presumed paraneoplastic aetiology, it is important to screen for associated malignancies.

- RS3PE has an excellent response on glucocorticoids and also the CTS symptoms resolve.

Competing interests None.

Patient consent Obtained.

\section{REFERENCES}

1 Olive $\mathrm{A}$, del Blanco J, Pons $\mathrm{M}$, et al. The clinical spectrum of remitting seronegative symmetrical synovitis with pitting edema. The Catalan Group for the Study of RS3PE. J Rheumatology 1997;24:333-6.

2 Bucaloiu ID, Olenginski TP, Harrington TM. Remitting seronegative symmetrical synovitis with pitting edema syndrome in a rural tertiary care practice: a retrospective analysis. Mayo Clin Proc. 2007;82:1510-15.

3 Cantini F, Salvarini C, Olivieri I, et al. Remitting seronegative symmetrical synovitis with pitting oedema (RS3PE) syndrome: a prospective follow up and magnetic resonance imaging study. Ann Rheum Dis 1999:58:230-6. 
Copyright 2012 BMJ Publishing Group. All rights reserved. For permission to reuse any of this content visit http://group.bmj.com/group/rights-licensing/permissions.

BMJ Case Report Fellows may re-use this article for personal use and teaching without any further permission.

Become a Fellow of BMJ Case Reports today and you can:

- Submit as many cases as you like

- Enjoy fast sympathetic peer review and rapid publication of accepted articles

- Access all the published articles

- Re-use any of the published material for personal use and teaching without further permission

For information on Institutional Fellowships contact consortiasales@bmjgroup.com

Visit casereports.bmj.com for more articles like this and to become a Fellow 